\title{
Novel Viewpoints on Tobacco Smoking and COVID-19
}

\author{
Sachin Sarode ${ }^{1}$, Gargi Sarode ${ }^{2}$, Dinesh Rajput ${ }^{3}$, Nilesh K Sharma ${ }^{4}$, Ayushi Kaushik ${ }^{5}$, Shankargouda Patil ${ }^{6}$ \\ The Journal of Contemporary Dental Practice (2020): 10.5005/jp-journals-10024-2910
}

We read with great interest an article by Karanasos et al. titled "Impact of smoking status on disease severity and mortality of hospitalized patients with COVID-19 infection: a systematic review and meta-analysis". ${ }^{1}$ It is inferred that there is an adverse impact of smoking on disease severity and mortality of hospitalized COVID-19 patients, which is more pronounced in younger patients without diabetes. Literature is flooded with papers on possible interaction and outcome of COVID-19 association with smoking. However, there are still conflicting views on the effect of smoking in patient outcomes. These conclusions are data-driven and lack valid pathogenetic background for interpretation.

The important and main event in the disease process of COVID-19 infection is the attachment of spike receptors with the ACE-2 of the host cells. Lungs are the most abundant source of ACE-2 receptors and hence are the most common site for the COVID-19 infection. Previously known discussions on COVID-19 and smoking were related to ACE-2 receptor upregulation and nicotine interaction with acetylcholine receptors. ${ }^{2,3}$ Possible negative and positive effects of these mechanisms were extensively discussed in the literature but failed to reach a concrete consensus. Hence, the possibility of a major role of some unknown factors is sensed and efforts have been made to discuss some of the novel aspects, which can potentially take place in COVID-19 patients with a smoking background.

- Nicotine and metabolized products may enforce target cells to achieve epigenetic changes that may not be favorable to the integration and perpetuation of the genetic material of COVID-19 in infected epithelial cells. Hence, $\mathrm{N}$-methylnicotinium, nicotine imine, and norcotinine may be explored in terms of genetic and epigenetic changes in the target cells. We believe that intracellular impacts of nicotine-metabolized products are more pronounced at genetic and epigenetic levels over nicotine. Hence, a speculative heterogeneity in terms of nicotine metabolic degradation patterns among smokers is proposed. It might have a direct relation with the severity of COVID-19 infection and future studies are warranted in this direction.

- Due to smoking-associated chemical irritation, lung stromal bed is already armed with the defense mechanism in the form of inflammatory cells and their mediators. ${ }^{4}$ Hence, when COVID-19 encounters such a proactive microenvironment, it will certainly have an effect on the disease progression as well as on the cytokine storm which is the classically associated comorbidity. Due to the preparedness of lung tissues, we believe that there will be less severe manifestations.

- Tar is a chemical substance produced from tobacco smoke and contains toxins, such as carbon monoxide, ammonia, and hydrogen cyanide. Tar is difficult to get removed instantly from the lung and in chronic smokers it always present. ${ }^{5}$ We believe
1,2,5 Department of Oral Pathology and Microbiology, Dr DY Patil Dental College and Hospital, Dr DY Patil Vidyapeeth, Pimpri, Pune, Maharashtra, India

${ }^{3}$ Department of Oral Pathology and Microbiology, YCMM and RDF's Dental College \& Hospital, Ahmednagar, Maharashtra, India

${ }^{4}$ Cancer and Translational Research Laboratory, Dr DY Patil Biotechnology and Bioinformatics Institute, Dr DY Patil Vidyapeeth, Tathawade, Pune, Maharashtra, India

${ }^{6}$ Department of Maxillofacial Surgery and Diagnostic Sciences, Division of Oral Pathology, College of Dentistry, Jazan University, Jazan, Kingdom of Saudi Arabia

Corresponding Author: Sachin Sarode, Department of Oral Pathology and Microbiology, Dr DY Patil Dental College and Hospital, Dr DY Patil Vidyapeeth, Pimpri, Pune, Maharashtra, India, Phone: +91 9922491465, e-mail: drsachinsarode@gmail.com

How to cite this article: Sarode $S$, Sarode G, Rajput D, et al. Novel Viewpoints on Tobacco Smoking and COVID-19. J Contemp Dent Pract 2020;21(9):949-950.

Source of support: Nil

Conflict of interest: None

that tar could be a hindrance in the attachment of the COVID-19 virus with the ACE-2 receptor. Since tar is a concentrate of the aforementioned harmful chemicals, there is also a possibility of antiviral action against the COVID-19 infection. This could be the reason for less percentage of smokers in the hospitaladmitted patients.

- Smoking causes squamous metaplasia of the respiratory epithelium. Apart from morphological changes, other alterations, such as the formation of keratohyalin like granules, increase cytokeratin content, and loss of cilia on the surface, are the characteristic features. ${ }^{6}$ This could have an impact on the COVID-19 progression inside the cells. However, the nature of the impact is the future scope of the research.

In conclusion, despite many research papers on the association of COVID-19 and smoking, there are no strong consensuses on the response outcomes. In the present paper, efforts were made to discuss four novel circumstances, which if investigated in the future could lead to give the appropriate answer to this association. We also register the possibility of algorithmic association of these as well as previously proposed events in affecting the outcome of this deadly association.

\section{References}

1. Karanasos A, Aznaouridis K, Latsios G, et al. Impact of smoking status on disease severity and mortality of hospitalized patients

(-) The Author(s). 2020 Open Access This article is distributed under the terms of the Creative Commons Attribution 4.0 International License (https://creativecommons. org/licenses/by-nc/4.0/), which permits unrestricted use, distribution, and non-commercial reproduction in any medium, provided you give appropriate credit to the original author(s) and the source, provide a link to the Creative Commons license, and indicate if changes were made. The Creative Commons Public Domain Dedication waiver (http://creativecommons.org/publicdomain/zero/1.0/) applies to the data made available in this article, unless otherwise stated. 
with COVID-19 infection: a systematic review and metaanalysis. Nicotine Tob Res 2020: ntaa107. DOI: 10.1093/ntr/ ntaa107.

2. Russo P, Bonassi S, Giacconi R, et al. COVID-19 and smoking: is nicotine the hidden link? Eur Respir J 2020;55(6):2001116. DOI: 10.1183/13993003.01116-2020.

3. Cure E, Cumhur Cure M. Angiotensin-converting enzyme inhibitors and angiotensin receptor blockers may be harmful in patients with diabetes during COVID-19 pandemic. Diabetes Metab Syndr 2020;14(4):349-350. DOI: 10.1016/j.dsx.2020. 04.019.
4. Lapperre TS, Postma DS, Gosman MM, et al. Relation between duration of smoking cessation and bronchial inflammation in COPD. Thorax 2006;61(2):115-121. DOI: 10.1136/thx.2005.040519.

5. Benowitz NL, Jacob 3rd P, Kozlowski LT, et al. Influence of smoking fewer cigarettes on exposure to tar, nicotine, and carbon monoxide. N Engl J Med 1986;315(21):1310-1313. DOI: 10.1056/ NEJM198611203152102.

6. Rigden HM, Alias A, Havelock T, et al. Squamous metaplasia is Increased in the bronchial epithelium of smokers with chronic obstructive Pulmonary disease. PLoS One 2016;11(5):e0156009. DOI: 10.1371/journal.pone.0156009. 